\title{
Chapter 6 \\ Consecutive Field Trials of Rice Cultivation in Partially Decontaminated Paddy Fields to Reduce Radiocesium Absorption in the Iitate Village in Fukushima Prefecture
}

\section{Ichio Ii and Keitaro Tanoi}

\begin{abstract}
We performed consecutive field trials of rice cultivation to reduce radiocesium $\left({ }^{134} \mathrm{Cs}\right.$ and $\left.{ }^{137} \mathrm{Cs}\right)$ absorption by rice in a partially decontaminated paddy soil in the Iitate Village in Fukushima prefecture, Japan. People had evacuated this area because of the high levels of radioactive contamination caused by the nuclear disaster in 2011 at the Fukushima Daiichi Nuclear Power Station, Tokyo Electric Power. The radiocesium concentrations were measured for paddy soil and for lowland rice grown on variously decontaminated paddy soil in 2012 and 2013. The results show that the radiocesium concentration in the brown rice cultured in the fields of Sasu and Maeda with $2000-6000 \mathrm{~Bq} / \mathrm{kg}$ dry weight (0-15 cm average soil depth) was below $40 \mathrm{~Bq} / \mathrm{kg}$, which is below the Japanese new standard for food $(100 \mathrm{~Bq} / \mathrm{kg})$. In addition, the radiocesium concentration in the brown rice depended on the decontamination level of the paddy soil. In addition, the radiocesium concentration in the rice was reduced depending on the exchangeable $\mathrm{K}$ content of the soil, which plateaued around $20 \mathrm{mg} \mathrm{K} \mathrm{K}_{2} \mathrm{O}$ per $100 \mathrm{~g}$ dry soil. However, in 2013, in a test field of Komiya where the radiocesium concentrations were higher than $8000 \mathrm{~Bq} / \mathrm{kg}$ dry weight, brown rice with more than $100 \mathrm{~Bq} / \mathrm{kg}$ was harvested, indicating the need for further decontamination. Overall, our results show that decontamination and additional $\mathrm{K}$ fertilization can reduce the radiocesium concentration in rice to less than the new standard, and that we could resume rice cultivation in the Iitate village by rather practical way.
\end{abstract}

Keywords Radioactive fallout $\bullet$ Soil $\bullet$ Rice $・$ Tokyo electric power $・$ Fukushima Daiichi nuclear accident $\bullet$ Cesium134 $\bullet$ Cesium137

\footnotetext{
I. Ii $(\bowtie)$

NPO Resurrection of Fukushima, 1-3-6-2 F1, Asagayakita, Suginami-ku, Tokyo 166-0004, Japan

e-mail: Iii1234@chive.ocn.ne.jp

K. Tanoi

Graduate School of Agricultural and Life Sciences, The University of Tokyo, 1-1-1, Yayoi, Bunkyo-ku, Tokyo 113-8657, Japan
} 


\subsection{Introduction}

Rice is the most important crop in Japan. The Fukushima Daiichi nuclear accident in March 2011 caused radioactive material to spread out and down onto farm lands from the Fukushima Daiichi Nuclear Power Plant of Tokyo Electric Power, particularly in Fukushima prefecture. In the Iitate Village, Fukushima prefecture, people are still prohibited to live at home and to cultivate rice on their farms. It is an important issue for them to judge whether they can resume rice cultivation in the village within the next few years. Radiocesium $\left({ }^{134} \mathrm{Cs}\right.$ and $\left.{ }^{137} \mathrm{Cs}\right)$ is assumed to be the radioactive material of most concern at present, considering the quantity released and its half-life. In 1997, Tsukada et al. (2002, 2005) performed experimental cultivation of rice in the Rokkasyo Village in Aomori prefecture and measured ${ }^{137} \mathrm{Cs}$ in the soil and in rice parts. The ${ }^{137} \mathrm{Cs}$ level for the dry soil was 4.4 $\mathrm{Bq} / \mathrm{kg}$ and the most was assumed to have derived from the many atmospheric atomic bomb experiments performed during the 1950s and 1960s. They reported that the ${ }^{137} \mathrm{Cs}$ radioactivity in dry white rice was $0.0048 \mathrm{~Bq} / \mathrm{kg}$. From these values, the transfer factor of ${ }^{137} \mathrm{Cs}$ for white rice from soil was calculated to be 0.0011 . Uchida and Tagami (2007) reported the transfer factors of ${ }^{137} \mathrm{Cs}$ for brown rice cultivated in all of Japan to be 0.003-0.06 before the Fukushima disaster in 2011.

After the disaster, Ohmori et al. (2014) examined the effect of fertilization on the radiocesium concentration in rice grown in a paddy field in Kawamata-cho in Fukushima prefecture, and they revealed that excess $\mathrm{N}$ and $\mathrm{K}$ deficiency increased radiocesium accumulation in rice from the soil. Nobori et al. (2014) investigated the effect of $\mathrm{K}$ on the behavior of ${ }^{137} \mathrm{Cs}$ in hydroponically cultured rice plants and showed the importance of maintaining an appropriate $\mathrm{K}$ concentration before ear emergence to avoid ${ }^{137} \mathrm{Cs}$ contamination of the rice grains. In addition, in the confirmatory fieldwork, the Ministry of Agriculture, Forestry and Fisheries (MAFF 2012) reported that the radiocesium concentrations of brown rice cultivated in decontaminated paddy soils (Komiya and Kusanomukaioshi districts in the Iitate Village) were below $13 \mathrm{~Bq} / \mathrm{kg}$, but their relationship to the radiocesium concentrations in the soil was not clarified. Furthermore, the Fukushima prefecture agency and MAFF (in January 2013) and MAFF et al. (in March 2014) investigated the relationships between the radiocesium concentrations in brown rice and soil and the exchangeable $\mathrm{K}$ concentration in the soil and showed that the radiocesium concentrations in brown rice are negatively related to the concentrations of exchangeable $\mathrm{K}$ in soil. However, they also concluded that no clear relationship was observed between the radiocesium concentrations in brown rice and those of the soils where the rice was cultivated. Thus, we investigated the relationship between the radiocesium concentrations in the soil and in brown rice grown in variously decontaminated soils in test fields with and without $\mathrm{K}$ addition.

The approved specified NPO "Resurrection of Fukushima" (ROF; www. fukushima-saisei.jp/) is a volunteer organization that aims to rebuild lives and reconstruct agriculture-centered industries that have been affected by the nuclear power plant accident. The activities started by focusing on the Iitate Village in 2011 


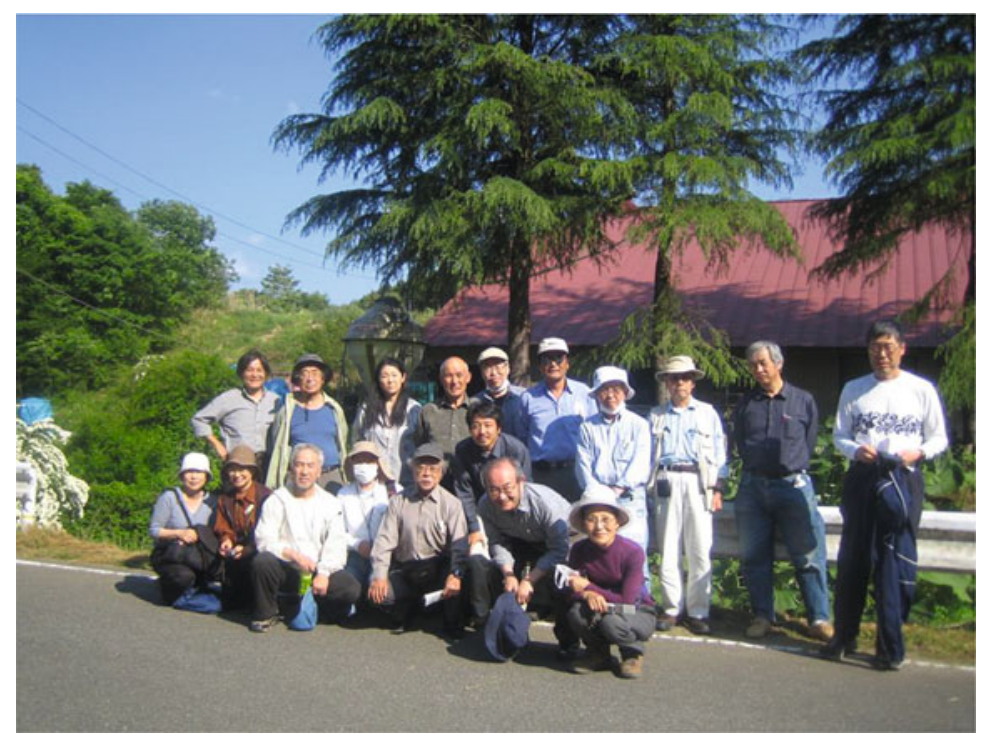

Fig. 6.1 The first visit to Iitate Village by volunteers in June 2011. A picture of Mr. Muneo Kanno with the visitors in front of his house in Sasu against the background of his bull barn and a stream. This visit provided the momentum to establish NPO "Resurrection of Fukushima" to work with villagers in the Iitate Village

in collaboration with the villagers (Fig. 6.1) and with assistance from the Graduate School of Agricultural and Life Sciences, University of Tokyo. The collaboration was facilitated by letter exchanges between the village head and the director of the faculty. One of the most important activities was that we annually cultivated rice in 2012, 2013, and 2014 in the Iitate Village, focusing on radiocesium in brown rice in relation to the level of decontamination of soil cultivated, with or without the addition of $\mathrm{KCl}$ fertilizer.

\subsection{Experimental Rice Cultivation Procedures in 2012}

Figure 6.2 shows diagrams and pictures of the test fields in the Iitate Village in 2012: (a) Sasu test fields $\left(\mathrm{N} 37^{\circ} 44^{\prime}, \mathrm{E} 140^{\circ} 43^{\prime}\right)$ in Sasu district and (b) Maeda test fields $\left(\mathrm{N} 37^{\circ} 43^{\prime}, \mathrm{E} 140^{\circ} 40^{\prime}\right)$ in Maeda district. The Sasu test fields were partially decontaminated in April 2012 by irrigating a paddy field with water to approximately 5-cm depth with rotary weeding tools, and the muddy water was then swept out (Mizoguchi 2013, Resurrection of Fukushima 2012).

The Sasu test fields were divided into fields A, B, C1, C2, and D, depending on the extent of decontamination. Each test field was divided into $\mathrm{N}$ (without additional $\mathrm{KCl}$ fertilizer) and $\mathrm{K}$ (with additional $\mathrm{KCl}$ fertilizer). The decontamination treatments were performed as follows: 
(a)
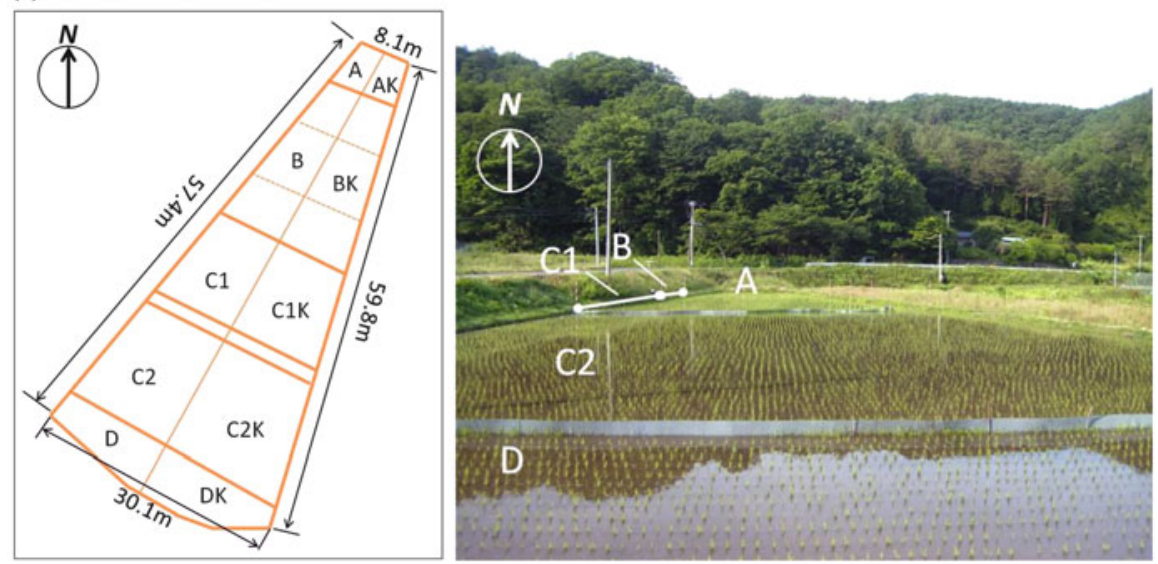

(b)
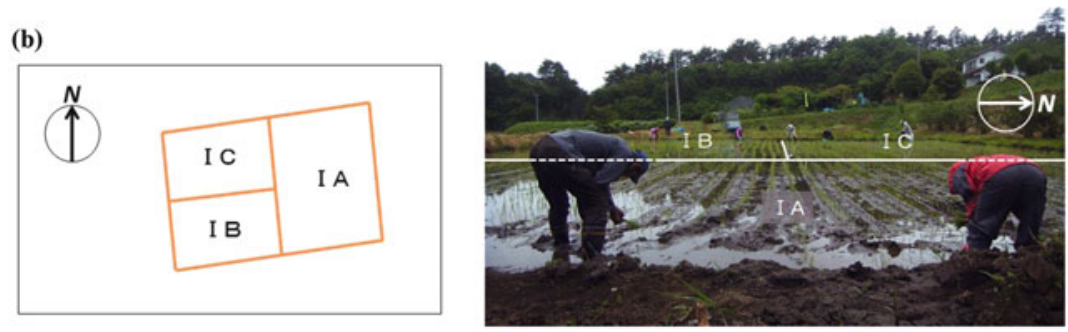

Fig. 6.2 The test fields of Sasu (a) and Maeda (b) in 2012 (Ii et al. 2015). (a) Left: diagram of test fields of Sasu. Right: picture of Sasu test fields just after the rice planting in June 2012. (b) Left: diagram of test fields of Maeda. Right: picture of Maeda test fields while rice planting in June 2012

A: Three cycles of shallow irrigation with rotary weeding tools and then drainage with a tennis court brush $(0.5$ acres $)$

B: One cycle of shallow irrigation with rotary weeding tools and then drainage with a tennis court brush (3.3 acres)

C1: Two cycles of shallow irrigation with a rotary weeding machine and then natural drainage (1.6 acres)

C2: One cycle of shallow irrigation with a rotary weeding machine and then natural drainage (5.2 acres)

D: No shallow irrigation (1.4 acres).

The Maeda test fields were divided into IA, IB, and IC with plowing and irrigating an approximately $15-\mathrm{cm}$ depth soil.

Rice seedlings of Akitakomachi were planted in Sasu and Maeda fields as shown in Fig. 6.2. Before planting, basal fertilizer $(12 \mathrm{~N}: 18 \mathrm{P}: 16 \mathrm{~K}: 4 \mathrm{Mg}$; weight $\%$ as $\mathrm{N}$, $\mathrm{P}_{2} \mathrm{O}_{5}, \mathrm{~K}_{2} \mathrm{O}$, and $\mathrm{MgO}$ ) was mixed with the plowed soil at $40 \mathrm{~kg}$ per 10 acres in Sasu test fields. In Maeda test fields, basal fertilizer (10N:8P:8K:2Mg) was mixed with the plowed soil at $40 \mathrm{~kg}$ per 10 acres. The $\mathrm{K}$ fertilizer was added as $\mathrm{KCl}(20 \mathrm{~kg}$ per 
10 acres) to $\mathrm{K}$ test fields with the basal fertilizer in Sasu. No $\mathrm{KCl}$ fertilizer was added to the Maeda test fields. No fertilizer was added after planting the rice.

Water was introduced to the test fields from a brook; the bottom water was blocked from entering. On rainy days, water was blocked from entering the Sasu test fields. For the Maeda test fields, bags of absorbent (Zeolite) were set at water entry points. The herbicide Sornet (Syngenta) was applied 1 week after rice planting. Electric nets were set to protect the fields from boar and monkey damage. Rice was harvested in mid-October in 2012. Figure 6.3 shows the test fields of Sasu (a) and Maeda(b) in October.

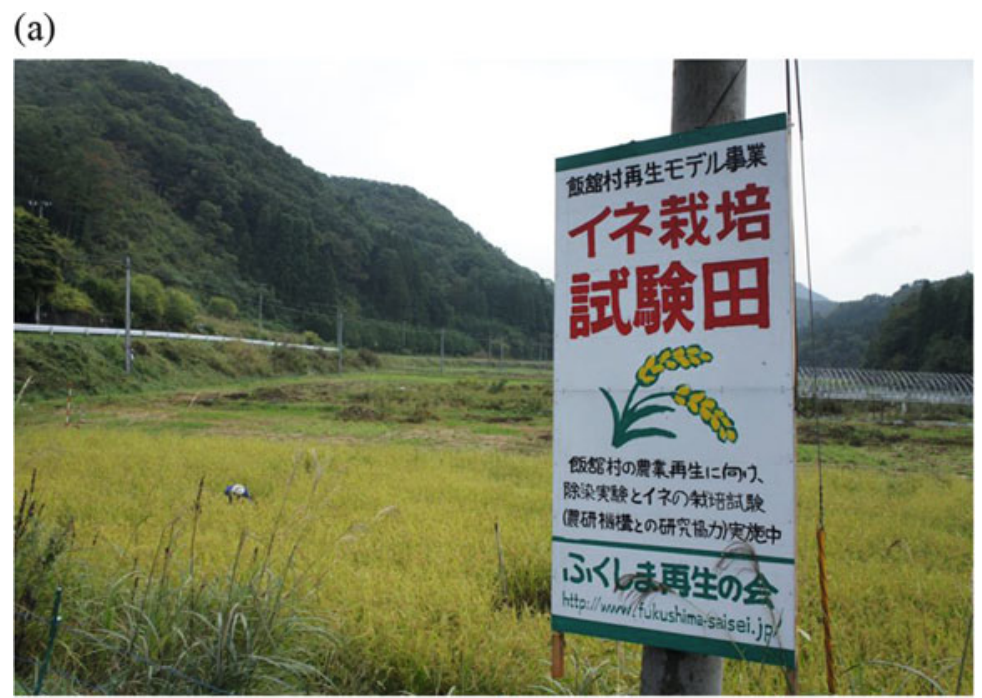

(b)

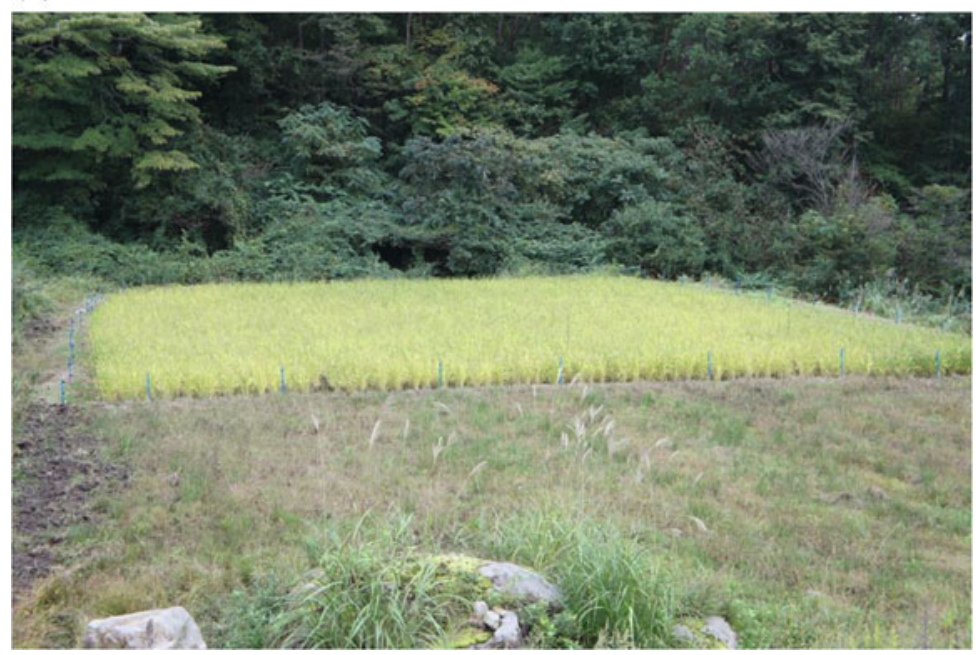

Fig. 6.3 (a) Sasu test fields with the sign in Japanese showing the rice cultivation trial on going by ROF. (b)Maeda test field at the mature stage in October 2012 
Rice sampling was performed at the dough stage on September 15-16 and at the mature stage on October 6-7. Following a five-point sampling procedure, five sampling points were assigned to each test field, and 10-20 sheaves of rice plant were then cut and collected (Fig. 6.4a). The bundles of rice were dried indoors for more than 1 week, and then the rice bundles from each test point were collected and threshed with an old-fashioned thresher (Fig. 6.4b) to give one unhulled rice sample for each test field. The unhulled rice was sent to "Circle Madei"(Fig. 6.5), a volunteer employee and student group at Tokyo University that collaborates with

(a)

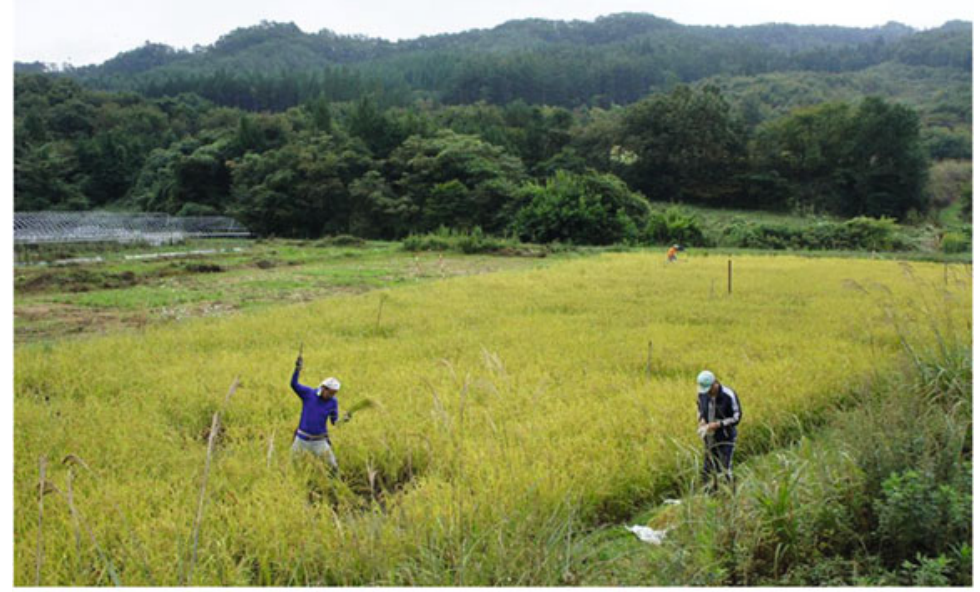

(b)

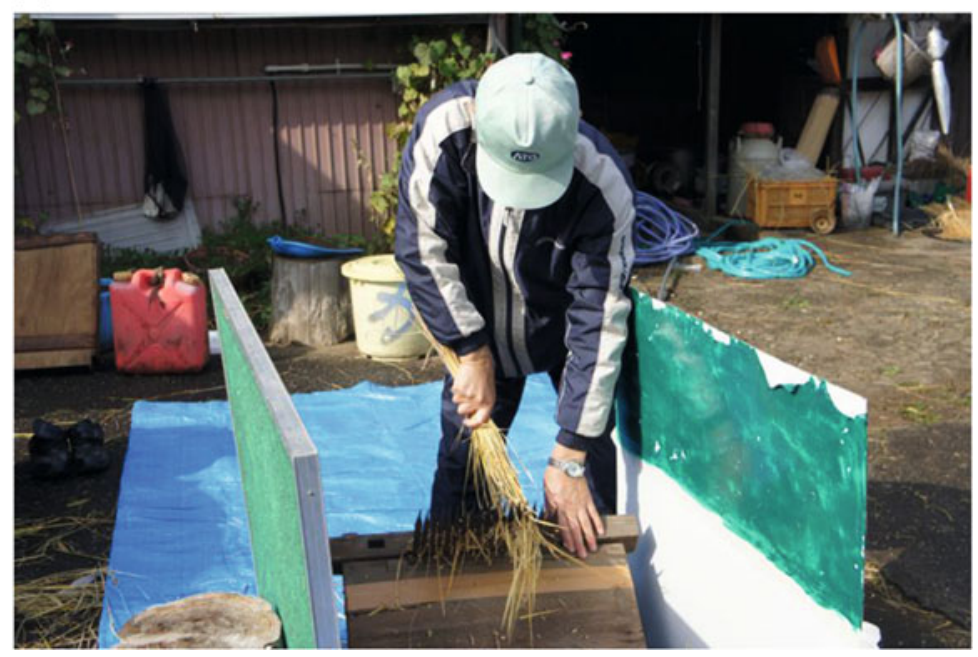

Fig. 6.4 (a) Sampling of sheaves of rice plants in test fields in Sasu in October 2012. (b) Threshing of rice bundles with an old-fashioned thresher to give unhulled rice in November 2012 
(a)

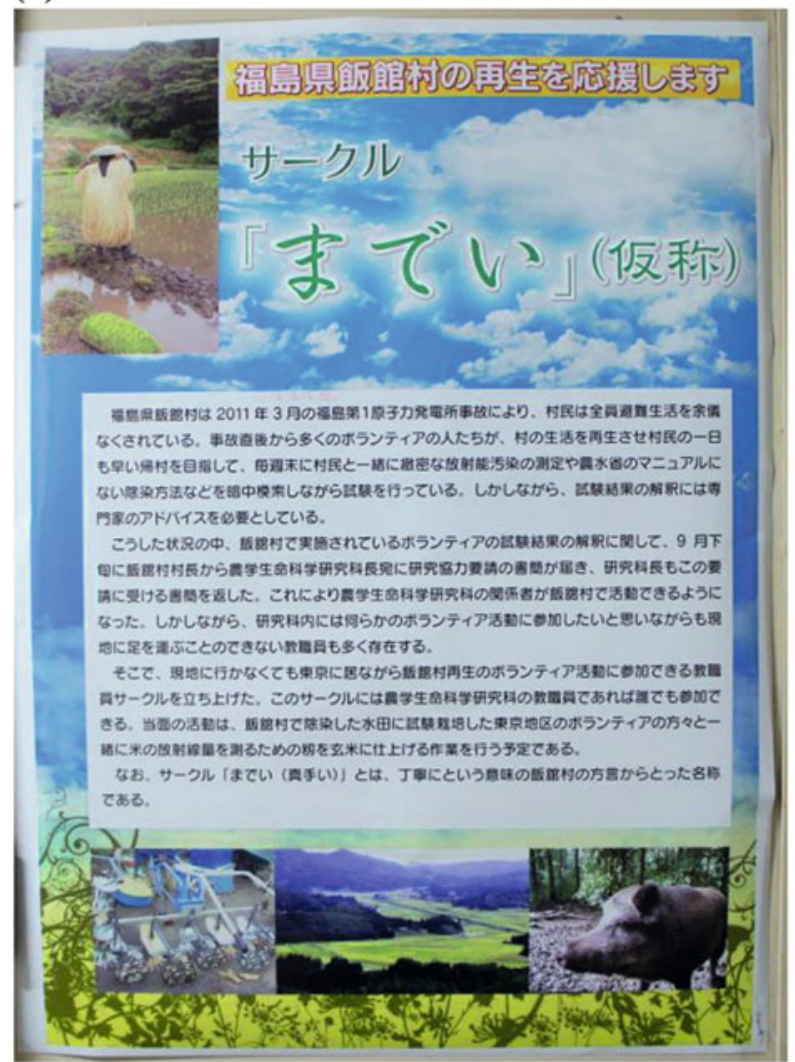

(b)

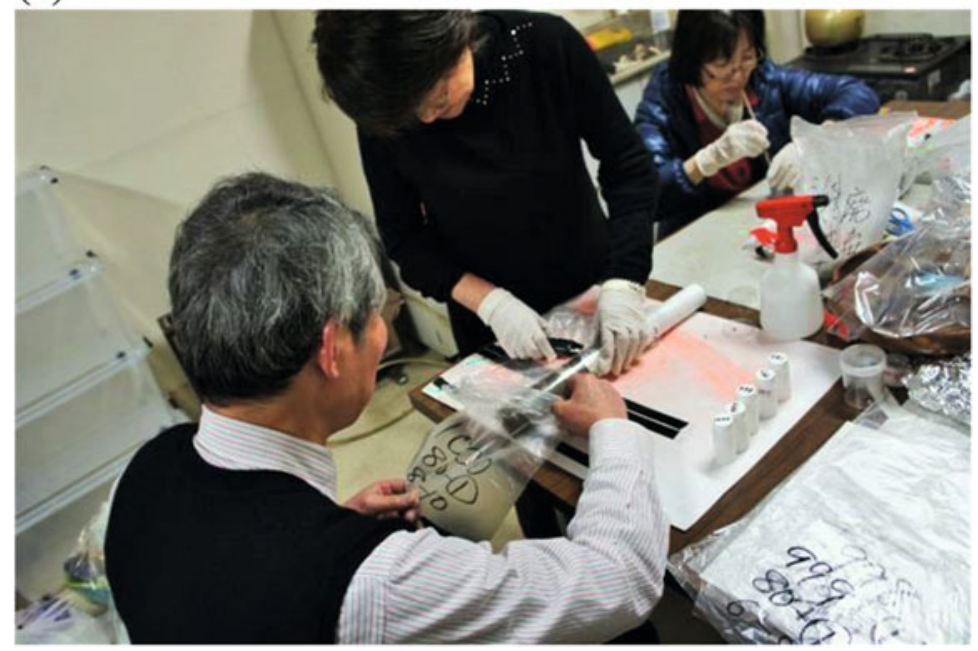

Fig. 6.5 (a) The poster of "Circle Madei" on the front of the circle room in the Graduate School of Agricultural and Life Sciences, University of Tokyo, showing its motivation in Japanese to support Iitate villagers to reconstruct their "Madei" life. "Madei" means polite, earnest, and steady, even if 
(a)

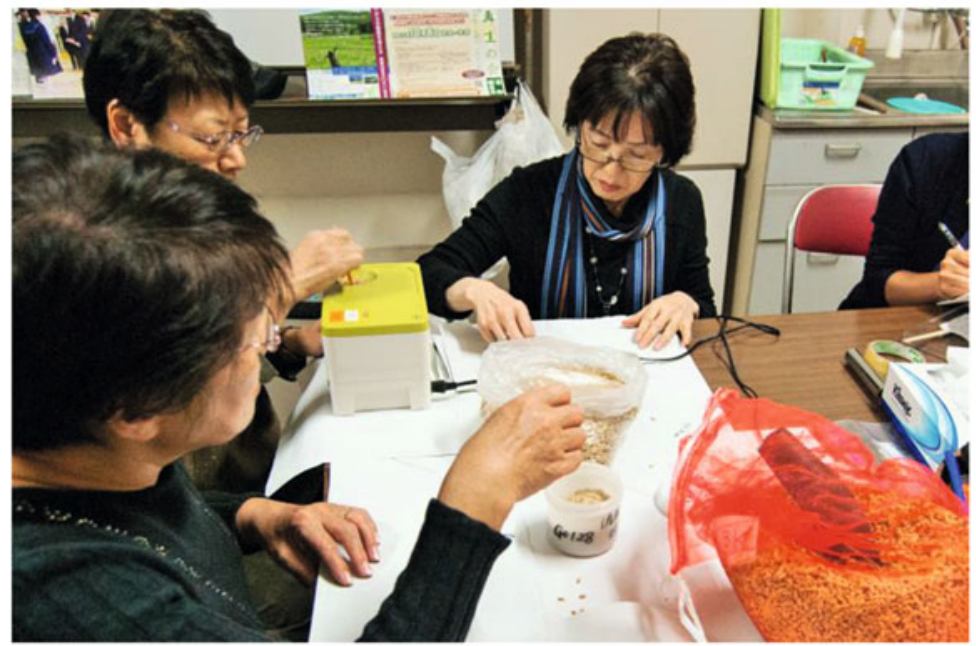

(b)

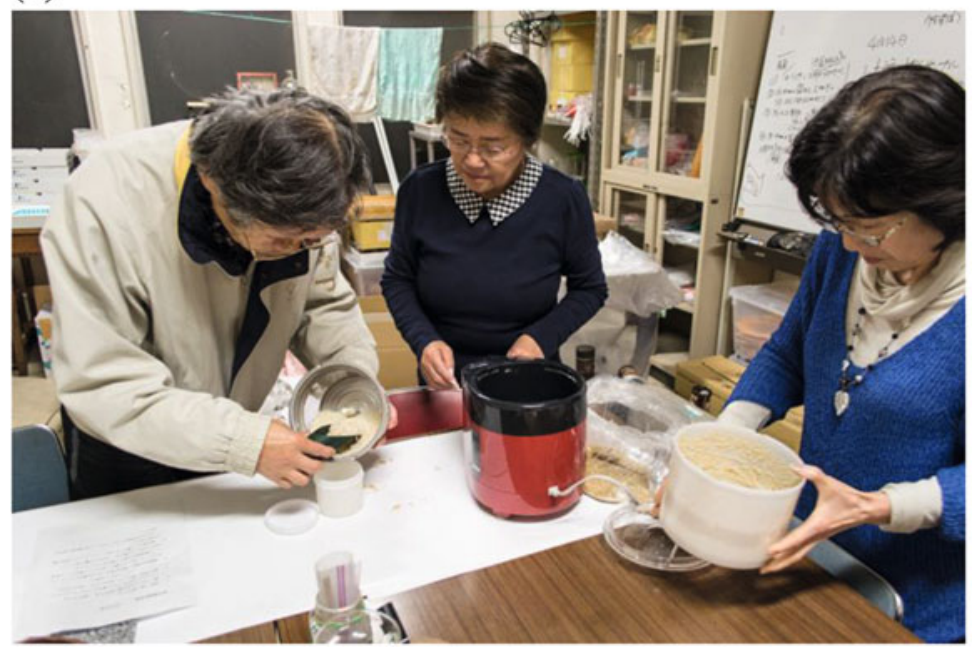

Fig. 6.6 (a) Hulling process of unhulled rice to give brown rice, being performed at "Circle Madei". (b) Polishing process of brown rice to give white rice and rice bran, being performed at "Circle Madei"

ROF to prepare samples for radioisotope measurement. The brown rice was prepared from the unhulled rice, using a hulling machine (Fig. 6.6a) and white rice and rice bran were prepared from the brown rice, using a rice polisher (Fig. 6.6b). The

Fig. 6.5 (continued) it may be slow (in dialect in Iitate Village, where they advocate "Madei" life). (b) Members of "Circle Madei", showing soil sample preparation No. 1000 in March 2013, since the start of November 2012. The number of samples reaching 10,000 in June 2015 
radiocesium measurements were performed at the Radioisotope Center, using a Ge semiconductor detector (GEM and GMX type; Seiko EG\&G) for rice samples in $250 \mathrm{ml}$ containers, and a $\mathrm{NaI}$ (Tl) Scintillation counter (2480WIZARD2 Auto ycounter; Perkin Elmer) for soil samples in $20 \mathrm{ml}$ vials (Nobori et al. 2013). The value of the soil was corrected per dry weight by measuring the soil weight after drying the soil at $60{ }^{\circ} \mathrm{C}$ for more than 6 days.

\subsection{Results of Experimental Cultivation in 2012}

\subsubsection{Radiocesium Concentrations of Brown Rice and Soil}

Figure 6.7 shows pictures of brown rice grains prepared at the dough stage and at the mature stage. Grains from the mature stage look browner than those from the dough stage. Figure 6.8 shows the radiocesium concentration of brown rice sampled from each test field at the dough stage and at the mature stage, respectively. Figure 6.9 shows the radiocesium concentration of soil $(0-15 \mathrm{~cm}$ average depth) for each test field. The radiocesium transfer factor for each stage at each test field is shown in Fig. 6.10 and was calculated from the data presented in Figs. 6.8 and 6.9. The brown rice measurements show that the radiocesium concentration from either stage was less than $40 \mathrm{~Bq} / \mathrm{kg}$. In the $\mathrm{KCl}$ fertilized fields $(\mathrm{AK}, \mathrm{BK}, \mathrm{C} 1 \mathrm{~K}, \mathrm{C} 2 \mathrm{~K}$, and $\mathrm{DK})$, the concentrations were below $25 \mathrm{~Bq} / \mathrm{kg}$. The transfer factors for brown rice were $0.002-0.008$, whereas those in the $\mathrm{KCl}$ fertilized field were $0.002-0.003$ at the dough stage and 0.003-0.004 at the mature stage.

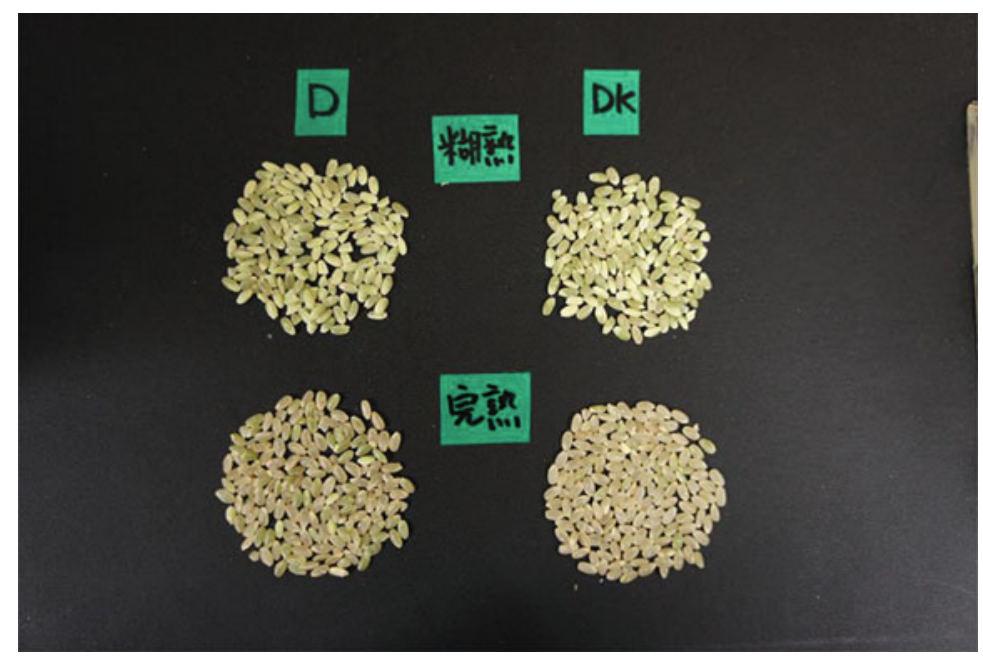

Fig. 6.7 Grains of brown rice prepared at the dough stage (upper) and at the mature stage (below) of test field D (left) and DK (right) in Fig. 6.2 


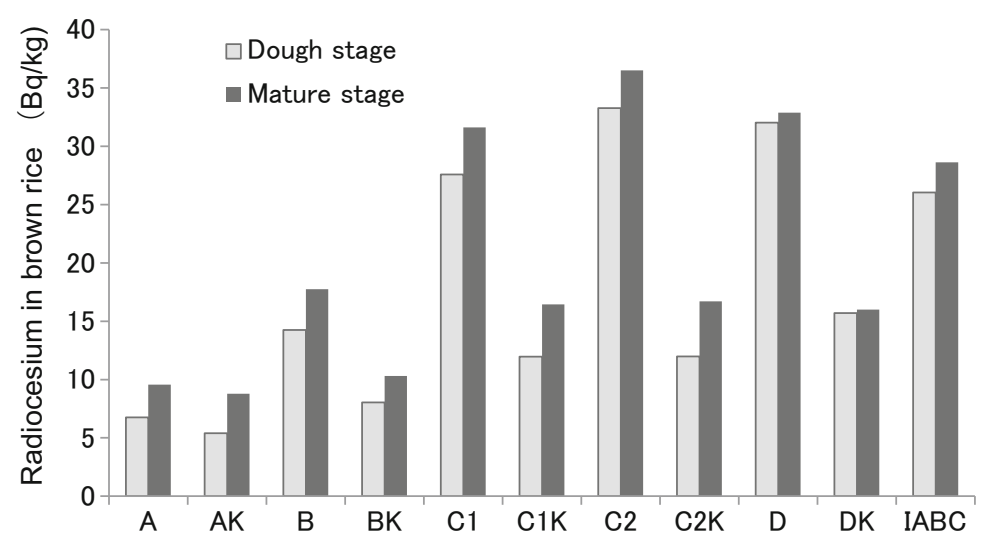

Fig. 6.8 The concentration of radiocesium in brown rice cultivated in Sasu (A-DK) and Maeda (IABC) in 2012 (Ii et al. 2015). Test fields are shown in Fig. 6.2

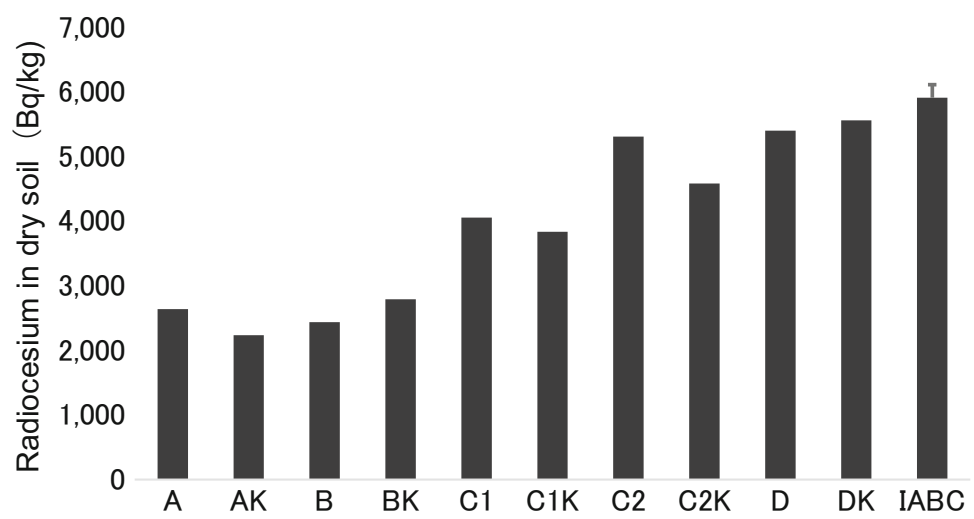

Fig. 6.9 The concentration of radiocesium in the soil ( $15 \mathrm{~cm}$ average depth) in 2012 (Ii et al. 2015). Test fields are shown in Fig. 6.2. The bar for IABC shows the SD of three soil samples (IA, IB, and IC)

Figure 6.11 shows the relationship between the radiocesium concentration in brown rice at the mature stage and that of the soil cultivated in the test field of Sasu for each group with $\mathrm{KCl}$ fertilizer $(\mathrm{K})$ and with no $\mathrm{KCl}$ added $(\mathrm{N})$. In both groups, the radiocesium concentration of brown rice tended to increase as the radiocesium concentration in the soil increased. A significant difference test of the correlation coefficient shows a significant $p$-value (0.032) for a group with only basal fertilizer added, but a non-significant $p$-value $(0.057)$ for a group with $\mathrm{KCl}$ fertilizer added (at the significant test level of 0.05 ). The inhibitory effect of $\mathrm{KCl}$ fertilizer on radiocesium in brown rice was clear $(p=0.026 ; t$-test, $\mathrm{n}=5)$. The radiocesium concentration in brown rice at the mature stage was approximately $10 \%$ higher than that from the dough stage (Fig. 6.8). The reason for this is unknown. 


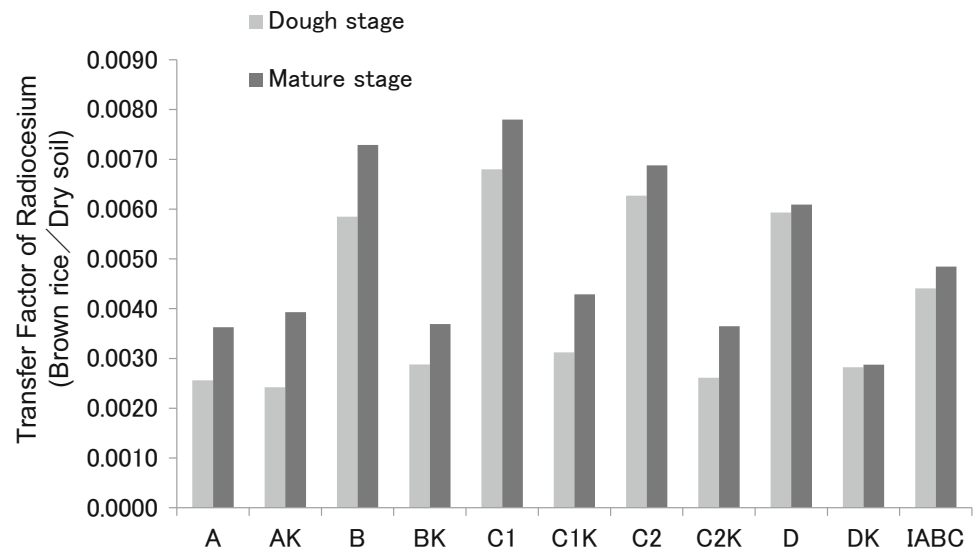

Fig. 6.10 The transfer factor of brown rice in 2012 calculated from the data shown in Figs. 6.8 and 6.9 (Ii et al. 2015). The test fields are shown in Fig. 6.2

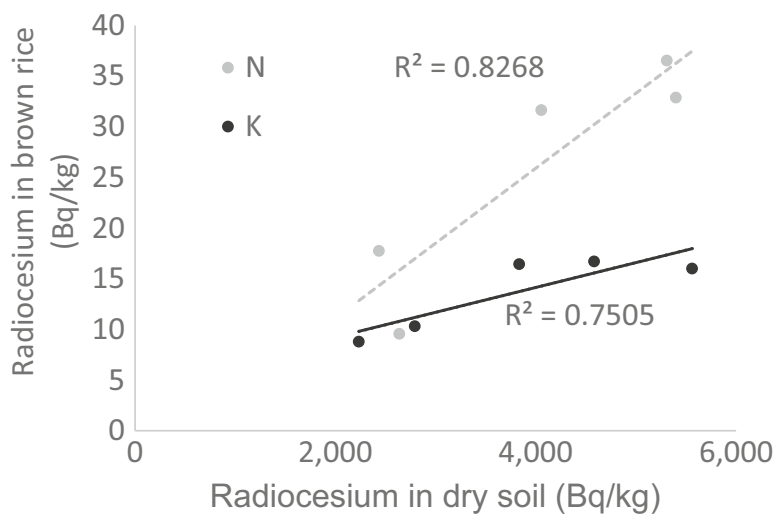

Fig. 6.11 The relationship of the radiocesium concentration between soil and brown rice cultivated in the test fields of Sasu in 2012 (Ii et al. 2015). The $p$-value between the two groups (K: with $\mathrm{KCl}$ fertilizer; $\mathrm{N}$ : no $\mathrm{KCl}$ fertilizer) was $0.026(t$-test, $\mathrm{n}=5)$

\subsubsection{Analyses of Exchangeable Cations in Soil from the Test Fields}

The soils measured for radiocesium were also analyzed for exchangeable cations using ICP-OES (Optima 7300DV) after extracting the dry soil with $1 \mathrm{M}$ ammonium acetate solution at room temperature for $24 \mathrm{~h}$. The results are shown in Fig. 6.12. The fields with added $\mathrm{KCl}(\mathrm{AK}, \mathrm{BK}, \mathrm{C} 1 \mathrm{~K}, \mathrm{C} 2 \mathrm{~K}$, and DK) had higher exchangeable $\mathrm{K}$ than the corresponding fields without $\mathrm{KCl}$ addition $(\mathrm{A}, \mathrm{B}, \mathrm{C} 1, \mathrm{C} 2$, and $\mathrm{D}$ ), respectively. However, there were significant differences between the test fields; for example, the exchangeable $\mathrm{K}$ content of $\mathrm{A}$ was much higher than for $\mathrm{B}, \mathrm{C} 1$, 

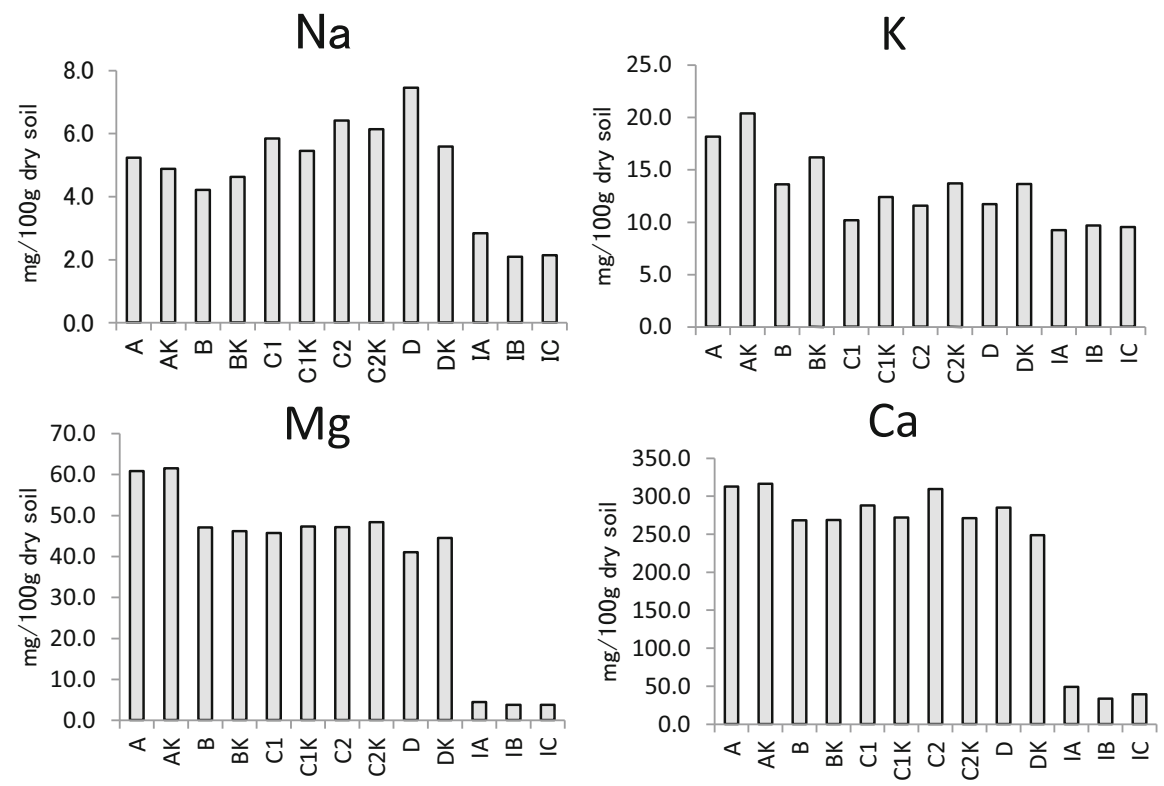

Fig. 6.12 Exchangeable cations of soil in Sasu and Maeda test fields in 2012 (Ii et al. 2015). Exchangeable $\mathrm{Na}, \mathrm{K}, \mathrm{Mg}$, and $\mathrm{Ca}$ in dry soil are expressed as $\mathrm{mg}$ per $100 \mathrm{~g}$ of dry soil (vertical axis)

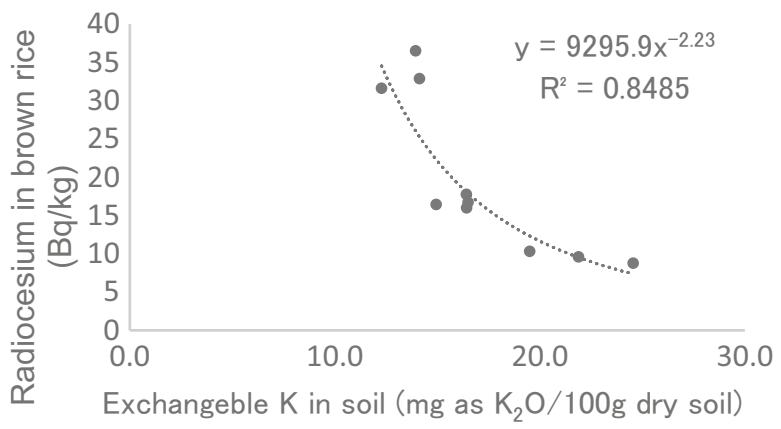

Fig. 6.13 Relationship of the radiocesium concentration in brown rice to exchangeable $\mathrm{K}$ in soil in Sasu test fields in 2012 (Ii et al. 2015). Exchangeable $\mathrm{K}$ is expressed in $\mathrm{mg}$ of $\mathrm{K}_{2} \mathrm{O}$ per $100 \mathrm{~g}$ of dry soil

$\mathrm{C} 2$, and D. All measured cation contents in the test fields of Maeda were much lower than those of Sasu. This is assumed to be because of the much higher sand content in the Madea field soil (IA, IB, and IC). This is also considered to be one of the causes of low rice yields in the Maeda test fields. Figure 6.13 shows the relationship between the radiocesium concentration in brown rice at the mature stage and exchangeable $\mathrm{K}$ in the soil in the Sasu test fields. A higher exchangeable $\mathrm{K}$ resulted in a significantly lower radiocesium concentration in cultivated brown 
rice. The radiocesium concentration in brown rice was below $10 \mathrm{~Bq} / \mathrm{kg}$ when the exchangeable $\mathrm{K}$ content was higher than $20 \mathrm{mg} / 100 \mathrm{~g}$ dry soil $\left(\mathrm{mg}\right.$ as $\mathrm{K}_{2} \mathrm{O}$ ). This indicates that maintaining exchangeable $\mathrm{K}$ content in soil higher than $20 \mathrm{mg} / 100 \mathrm{~g}$ is extremely important for reducing the radiocesium concentration of cultivated brown rice. This is consistent with the directive of National Agriculture and Food Organization (NARO 2012). The transfer factor of radiocesium in brown rice to that in soil was 0.003-0.004 when the exchangeable $\mathrm{K}$ content in soil was higher than $20 \mathrm{mg} / 100 \mathrm{~g}$. This is consistent with the lower range of reported values by Uchida and Tagami (2007).

\subsubsection{Radiocesium Concentration in White Rice and in Rice Bran}

Figure 6.14 shows the radiocesium concentrations in white rice and in rice bran prepared from the brown rice from each test field. The concentration in white rice was below half the value of brown rice and all were lower than $10 \mathrm{~Bq} / \mathrm{kg}$. The radiocesium concentrations in rice bran were more than double than that in brown rice. The values in some fields $(\mathrm{C} 2, \mathrm{D}$, and $\mathrm{IABC})$ were higher than $100 \mathrm{~Bq} / \mathrm{kg}$, although others harvested from partially decontaminated fields (A, B, and $\mathrm{C} 1)$ and from $\mathrm{KCl}$ added fields were below $100 \mathrm{~Bq} / \mathrm{kg}$ (the new standard for food in April 2012).

Thus, the 2012 field trials suggest that rice cultivation in the litate Village is feasible by reducing soil radiocesium by decontamination using shallow soil mixing and drainage, and by addition of $\mathrm{KCl}$ together with basal fertilizer.

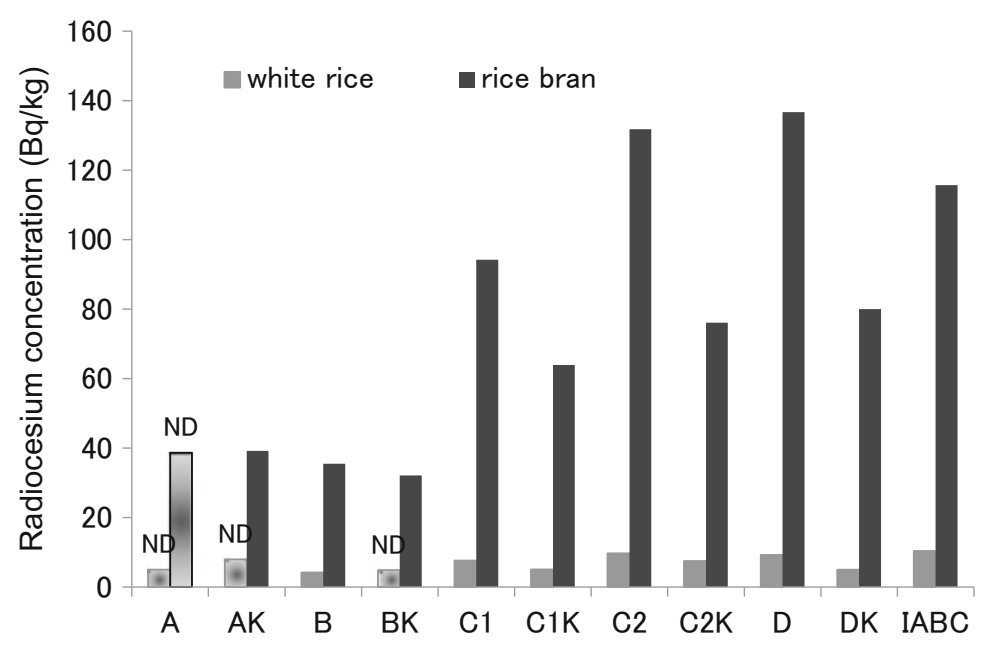

Fig. 6.14 Radiocesium concentration in white rice (left column) and rice bran (right column) harvested in each test field in 2012 (Ii et al. 2015). ND shows that both ${ }^{134} \mathrm{Cs}$ and ${ }^{137} \mathrm{Cs}$ are below the detection limit. The height of each ND column shows the sum of the detection limits of ${ }^{134} \mathrm{Cs}$ and ${ }^{137} \mathrm{Cs}$ 


\subsection{Experimental Cultivation of Rice in 2013}

In addition to Sasu and Maeda test fields in 2012, an experimental cultivation was performed in Komiya test fields $\left(\mathrm{N} 37^{\circ} 37^{\prime}\right.$, E140 $\left.46^{\prime}\right)$ in Komiya district (Fig. 6.15a, b) and in "Sasu Madei" test fields located to the eastern side of the

(a)

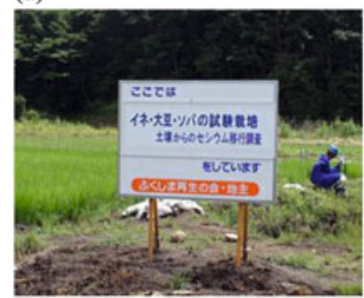

(b)

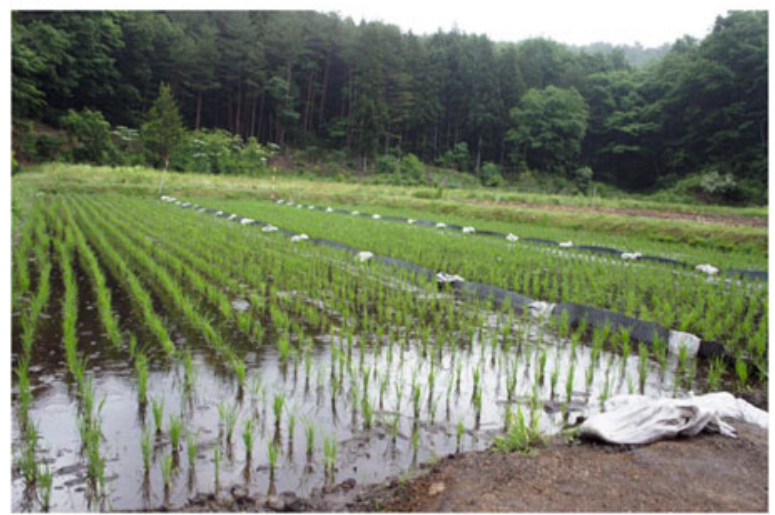

(c)

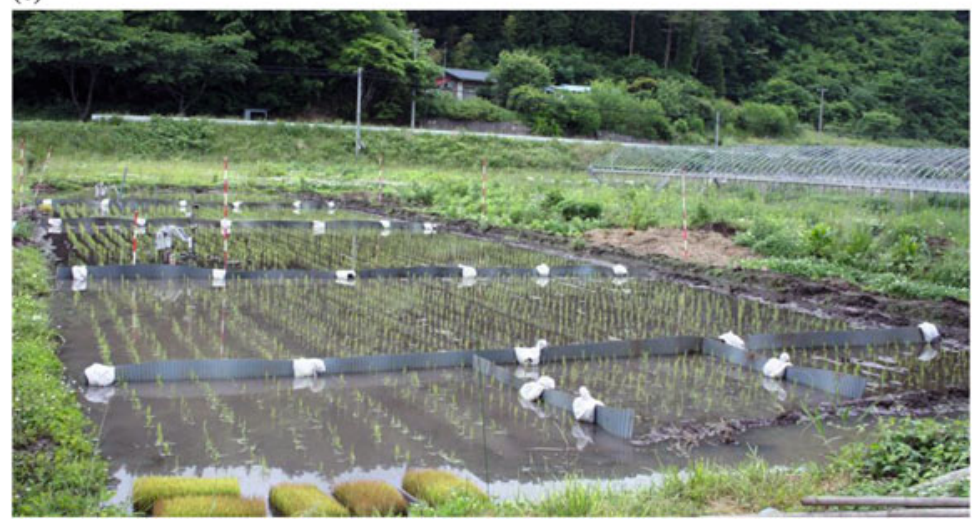

Fig. 6.15 (a) Komiya test fields in 2013, with the sign in Japanese showing that test cultivation was in progress. (b) Komiya test fields just after rice planting in August 2013. (c) "Sasu Madei" test fields just after rice planting in 2013 
Table 6.1 Description of test paddy fields in 2013. N: K not added, K: $\mathrm{KCl}$ added (Ii et al. 2015)

\begin{tabular}{|c|c|c|c|}
\hline Farm & Decontamination method (year) & Test field name & $\begin{array}{l}\mathrm{KCl} \\
\text { added or } \\
\text { not }\end{array}$ \\
\hline \multirow[t]{3}{*}{ Komiya } & \multirow{3}{*}{$\begin{array}{l}\text { Deep irrigation (ca.15 cm depth, } \\
\text { 2013) }\end{array}$} & S3 3 cycles & $\mathbf{N}, \mathbf{K}$ \\
\hline & & S1 1 cycle & $\mathbf{N}, \mathbf{K}$ \\
\hline & & SO 0 cycle & $\mathbf{N}, \mathbf{K}$ \\
\hline Maeda & Deep irrigation (2012) & & $\mathbf{N}, \mathbf{K}$ \\
\hline \multirow[t]{3}{*}{ Sasu } & \multirow{3}{*}{$\begin{array}{l}\text { Shallow irrigation (ca.5 cm } \\
\text { depth, 2012) }\end{array}$} & AB: A and a part of B in 2012 & $\mathbf{N}, \mathbf{K}$ \\
\hline & & $\begin{array}{l}\text { WC: a part of B and C1 in } 2012 \\
\text { with straw plowed in the soil }\end{array}$ & N. K \\
\hline & & CD: $\mathrm{C} 2$ and D in 2012 & $\mathbf{N}, \mathbf{K}$ \\
\hline \multirow{6}{*}{$\begin{array}{l}\text { Sasu } \\
\text { Madei }\end{array}$} & \multirow{6}{*}{$\begin{array}{l}\text { Madei method (ca.5 cm depth of } \\
\text { surface soil removed, 2013) }\end{array}$} & W: Straw plowed in & $\mathbf{N}, \mathbf{K}$ \\
\hline & & $\mathbf{N}$ : No straw plowed in & $\mathbf{N}, \mathbf{K}$ \\
\hline & & T: Compost mixed in & $\mathbf{N}, \mathbf{K}$ \\
\hline & & $\begin{array}{l}\text { MK: } \mathrm{KCl} \text { added with basal fertil- } \\
\text { izer ( } 8 \text { in June) }\end{array}$ & $\mathbf{K}$ \\
\hline & & $\begin{array}{l}\text { YK: } \mathrm{KCl} \text { added during the panicle } \\
\text { formation stage ( } 28 \text { in July) }\end{array}$ & $\mathbf{K}$ \\
\hline & & $\begin{array}{l}\text { HK: } \mathrm{KCl} \text { added during the heading } \\
\text { stage (16 in August) }\end{array}$ & $\mathbf{K}$ \\
\hline
\end{tabular}

Sasu test fields in 2012 (Fig. 6.15c ). Table 6.1 shows a list of the test fields, treatment methods, test field names, and whether $\mathrm{KCl}$ was added or not. The straw harvested in 2012 (approximately $80 \mathrm{~kg} / \mathrm{acre}$ ) was plowed into some of the test fields (WC and $\mathrm{W}$ ) because straw contains high $\mathrm{K}$ and other nutrients and is generally recycled into the soil after rice harvest to keep the soil fertilized.

Rice cultivation at Sasu and Maeda was performed in a similar way to that in 2012, using Akitakomachi rice seedlings with some modifications. Briefly, basal fertilizer $12 \mathrm{~N}: 18 \mathrm{P}: 16 \mathrm{~K}: 4 \mathrm{Mg}$ ( $40 \mathrm{~kg}$ per 10 acres) was applied to all the test fields and $\mathrm{KCl}(20 \mathrm{~kg}$ per 10 acres) was applied to the test fields affixed with $\mathrm{K}$ in early June. Rice was planted in mid-June (Fig. 6.16) and then harvested in mid-October (Fig. 6.17). In the Komiya test fields, basal fertilizer 12N:18P:16K:4Mg (40 kg per 10 acres) was added in mid-May. Rice planting and $\mathrm{KCl}$ ( $20 \mathrm{~kg}$ per 10 acres) addition to $\mathrm{K}$ affixed test fields was performed in late May. The rice was harvested in early October. Rice sampling at the mature stage was performed at Sasu and Maeda in mid-October and at Komiya in early October. Measurements of radiocesium were performed the same way as those in 2012, except that rice bran was measured using an $\mathrm{NaI}(\mathrm{Tl})$ scintillation counter with $20 \mathrm{ml}$ vials. 
(a)

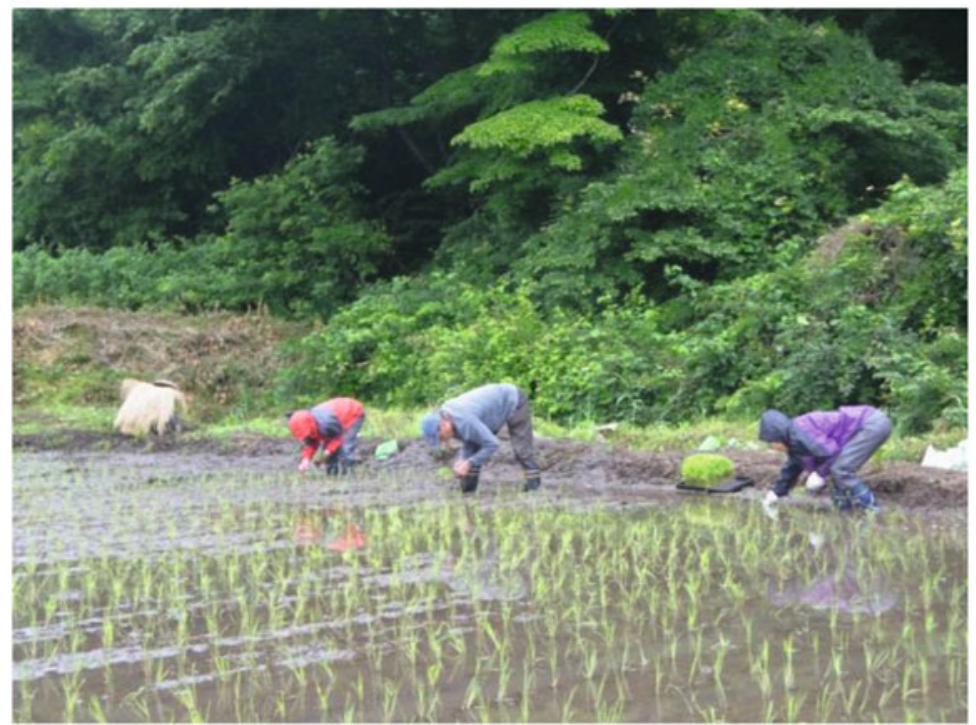

(b)

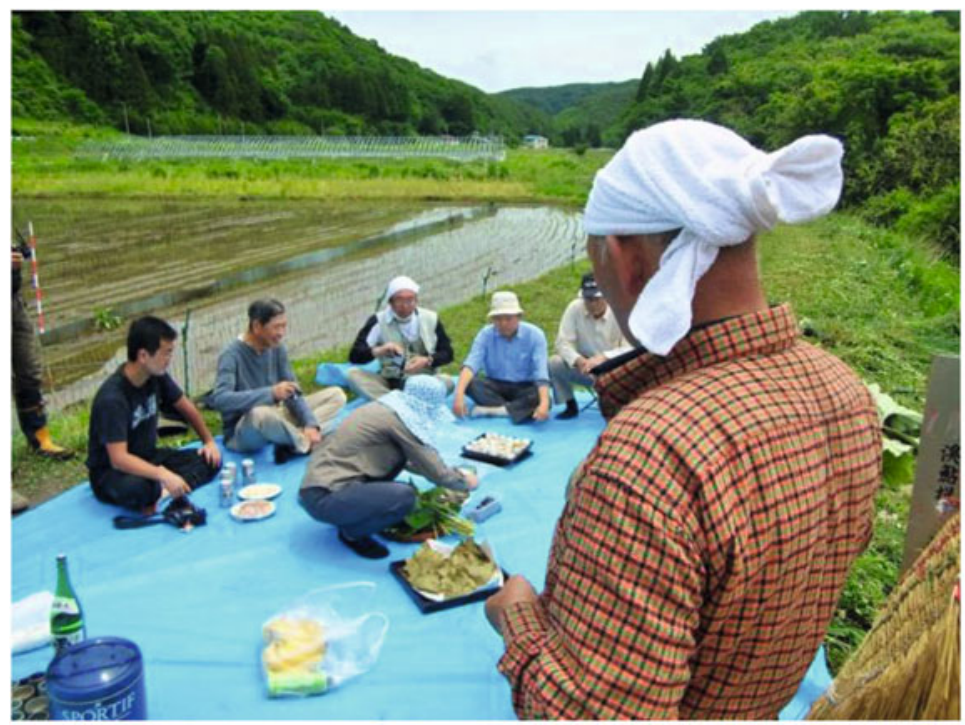

Fig. 6.16 (a) Maeda test field showing rice planting by members of ROF in June 2013. (b) Lunch to celebrate rice planting at the field close to Sasu test field in June 2012. After rice planting, we usually have dinner with sake (rice wine) to celebrate rice planting and pray for safe growth of rice with good weather 
(a)

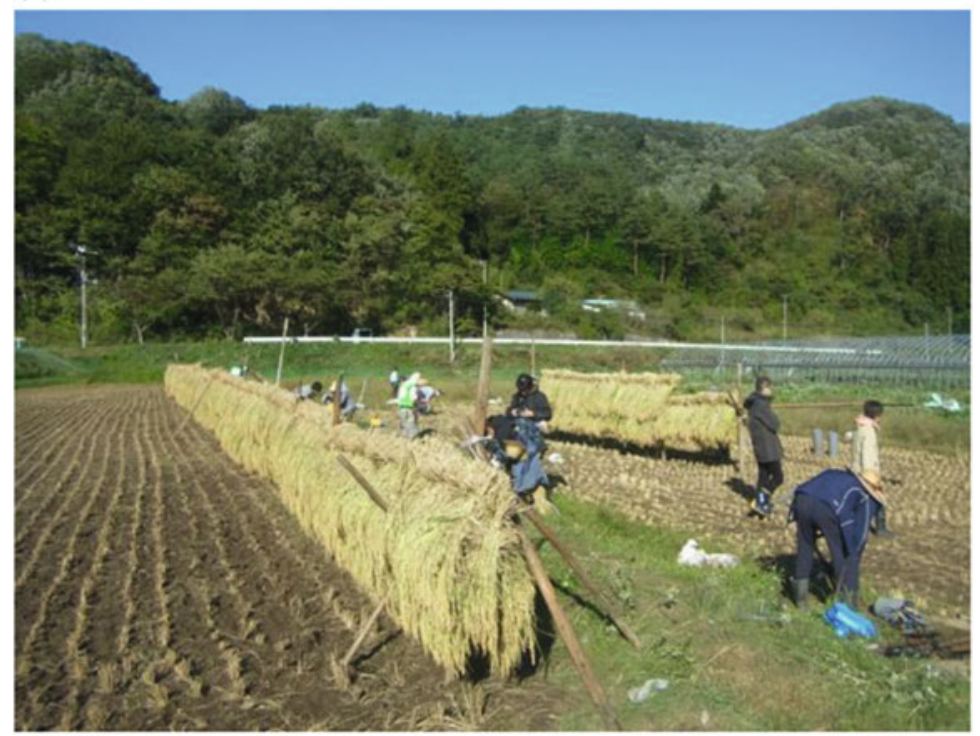

(b)

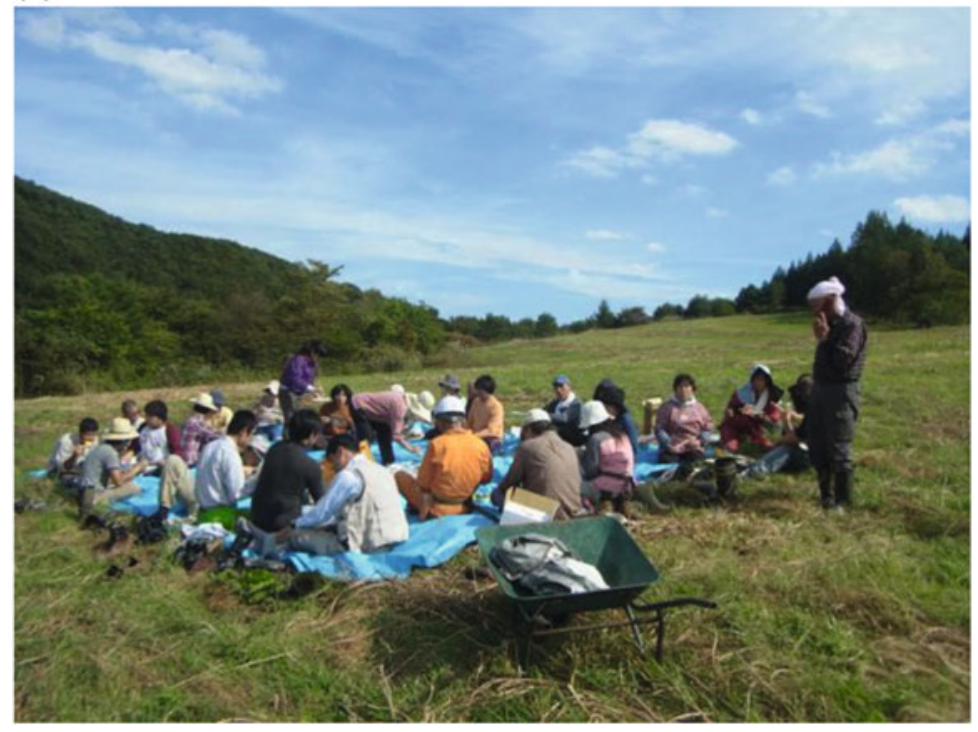

Fig. 6.17 (a) Havested rice hung for natural drying at Sasu in October 2013. (b) Lunch to celebrate rice harvest at Sasu in October 2012. Rice harvest is a most important event in farmer life in Japan 


\subsection{Results of Experimental Cultivation in 2013}

\subsubsection{Radiocesium Concentrations of Brown Rice and Soil}

Figure 6.18 shows the radiocesium concentrations of brown rice sampled at the mature stage and Fig. 6.19 shows the radiocesium concentrations of soil $(0-15 \mathrm{~cm}$ average depth) for each test field. The radiocesium transfer factor for each test field is shown in Fig. 6.20 and was calculated from the data in Figs. 6.18 and 6.19. Soil sampling at Komiya was performed from $\mathrm{N}$ sections and $\mathrm{K}$ sections together. In the test field of Maeda, soil sampling was not performed. In Komiya test fields, the radiocesium concentrations in the soil were high. This is due to high radiocesium concentrations before decontamination (around 14,000 Bq/kg dry soil measured in May 2013) and because the decontamination method of deep irrigation was not as effective as the shallow irrigation method performed at Sasu test fields in 2012. Furthermore, the differences in the radiocesium concentrations between $\mathrm{S} 0, \mathrm{~S} 1$, and

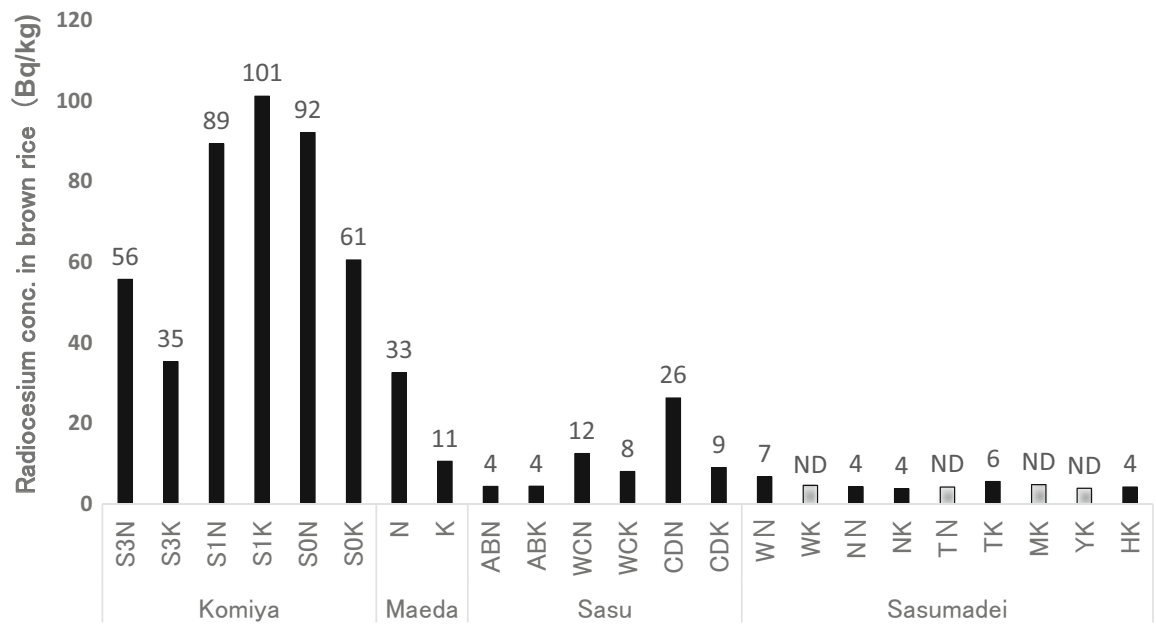

Fig. 6.18 The concentration of radiocesium in brown rice in 2013 (Ii et al 2015). The last letter "N" indicates the field "not $\mathrm{KCl}$ added" and the last letter " $\mathrm{K}$ " indicates the field " $\mathrm{KCl}$ added". Komiya: test fields of Komiya district (S3: decontaminated in 2013 by three cycles of mixing surface soil of approximately $15-\mathrm{cm}$ depth and drainage; $\mathrm{S} 1$ : the same as S3 except by one cycle of mixing; S0: the same as S3 except that there was no cycle of mixing). Maeda: test fields of Maeda district. Sasu: Sasu test fields of Sasu district decontaminated by rotary weeding method of mixing the surface soil to about 5-cm depth and drainage in 2012 (AB: A plus a part of B test field in 2012; WC: A part of B plus C1 test field in 2012 and straw harvested in 2012 was mixed in the soil; CD: C2 plus D in 2012). Sasumadei: Sasu test fields decontaminated by stripping approximately $5 \mathrm{~cm}$ of surface soil in 2013 (WN: straw was mixed in the soil, no KCl added; WK: straw was mixed in and $\mathrm{KCl}$ added; $\mathrm{NN}$ : no straw mixed in, no $\mathrm{KCl}$ added; $\mathrm{NK}$ : no straw mixed in, $\mathrm{KCl}$ added; $\mathrm{TN}$ : compost was mixed in, no $\mathrm{KCl}$ added; TK: compost was mixed in, $\mathrm{KCl}$ added; $\mathrm{MK}$ : $\mathrm{KCl}$ added with base fertilizer; $\mathrm{YK}: \mathrm{KCl}$ added during the panicle formation stage; $\mathrm{HK}: \mathrm{KCl}$ added during the heading stage). ND shows that both ${ }^{134} \mathrm{Cs}$ and ${ }^{137} \mathrm{Cs}$ are below the detection limit. The height of the ND columns show the sum of the detection limits of ${ }^{134} \mathrm{Cs}$ and ${ }^{137} \mathrm{Cs}$ 


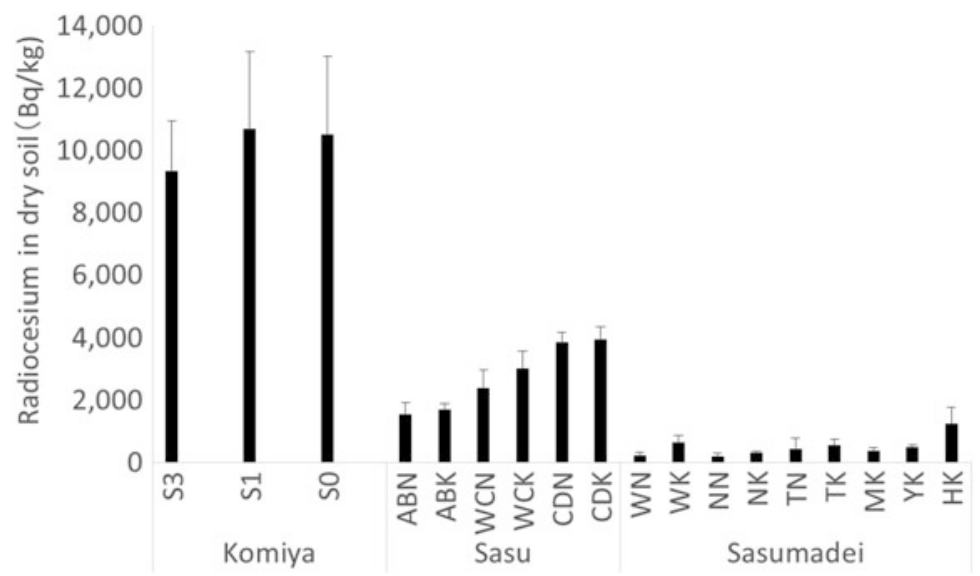

Fig. 6.19 The concentration of radiocesium in dry soil (15-cm average depth) in 2013 (Ii et al. 2015). The columns and bars show average and SD, respectively, of values of five soil points in each test field. Refer to Fig. 6.18 legend for details of the test fields

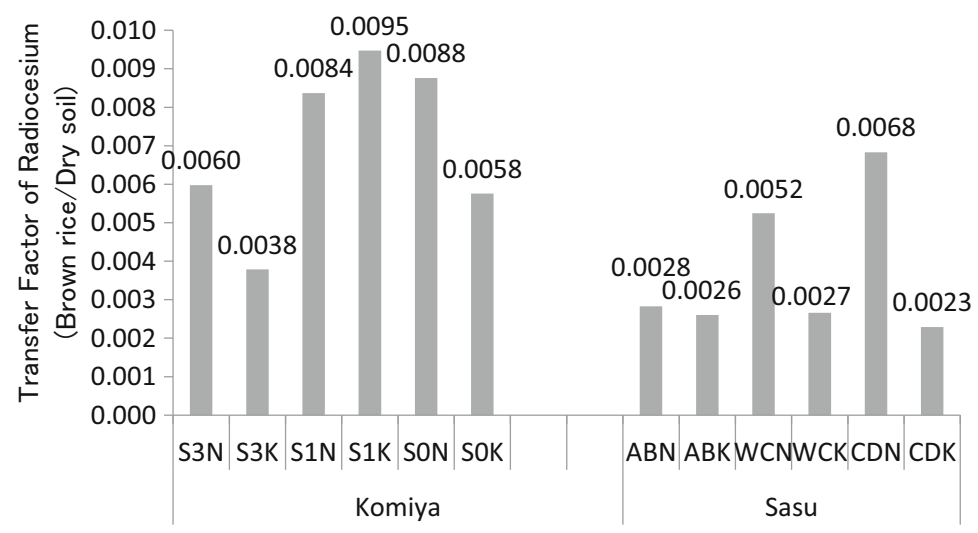

Fig. 6.20 Transfer factor of brown rice in 2013 calculated using the data shown in Figs. 6.18 and 6.19 (Ii et al. 2015). Refer to the legend of Fig. 6.18 for details of the test fields

S3 (Fig. 6.19) were less than the differences before planting the rice, which was probably due to soil transfer between the test fields and influx of radiocesium from the brook water (Nemoto and Abe 2013).

In the Sasu test fields, the radiocesium concentrations were $1500-4000 \mathrm{~Bq} / \mathrm{kg}$ and in a similar order to those in 2012 (Fig. 6.9; ABN, ABK $<$ WBN, WBK $<\mathrm{CDN}, \mathrm{CDK}$ ), although they were generally approximately $20 \%$ lower than in 2012. No significant increase in the radiocesium concentrations occurred for the soil in the WBN and WBK treatments that contained the plowed straw harvested in 2012.

In "Sasu Madei" test fields, the radiocesium concentrations of the soils were $200-600 \mathrm{~Bq} / \mathrm{kg}$, except for a test field of HK (southern corner field), showing that 
the "Madei Method" of stripping co. $5 \mathrm{~cm}$ surface soil was effective at reducing the radiocesium concentration.

The radiocesium concentration of brown rice from the test fields in Komiya were 35-101 Bq/kg. The S3N and S3K fields showed lower values than the corresponding fields S0N, S0K and S1N, S1K. Addition of $\mathrm{KCl}$ reduced radiocesium accumulation in brown rice in $\mathrm{S} 3$ and $\mathrm{S} 0$, but not in $\mathrm{S} 1$. The reason for high radiocesium concentrations in $\mathrm{S} 1 \mathrm{~K}$ is unclear. In the Maeda test fields, there was a clear effect of added $\mathrm{KCl}(33-11 \mathrm{~Bq} / \mathrm{kg})$. In the fields of Sasu, ABN and ABK had $4 \mathrm{~Bq} / \mathrm{kg}$ and WCB had $12 \mathrm{~Bq} / \mathrm{kg}$, whereas WCK had $8 \mathrm{~Bq} / \mathrm{kg}$. The CDN had $26 \mathrm{~Bq} / \mathrm{kg}$, whereas $\mathrm{CDK}$ had $9 \mathrm{~Bq} / \mathrm{kg}$. The reducing effect of $\mathrm{KCl}$ addition on the radiocesium concentrations in brown rice was observed in five test fields, excluding S1 in Komiya and AB. In "Sasu Madei”, all were below 7 Bq/kg.

The transfer factor for brown rice from Komiya and Sasu was 0.002-0.01 (Fig. 6.8). The reducing effect of $\mathrm{KCl}$ addition was clear, except for Komiya S1 field.

\subsubsection{Radiocesium Concentrations of White Rice and Rice Bran in 2013}

Figure 6.21 shows the radiocesium concentrations in white rice and in rice bran prepared from the brown rice from Komiya and Maeda. The radiocesium concentration in white rice were approximately half of that of brown rice. White rice from

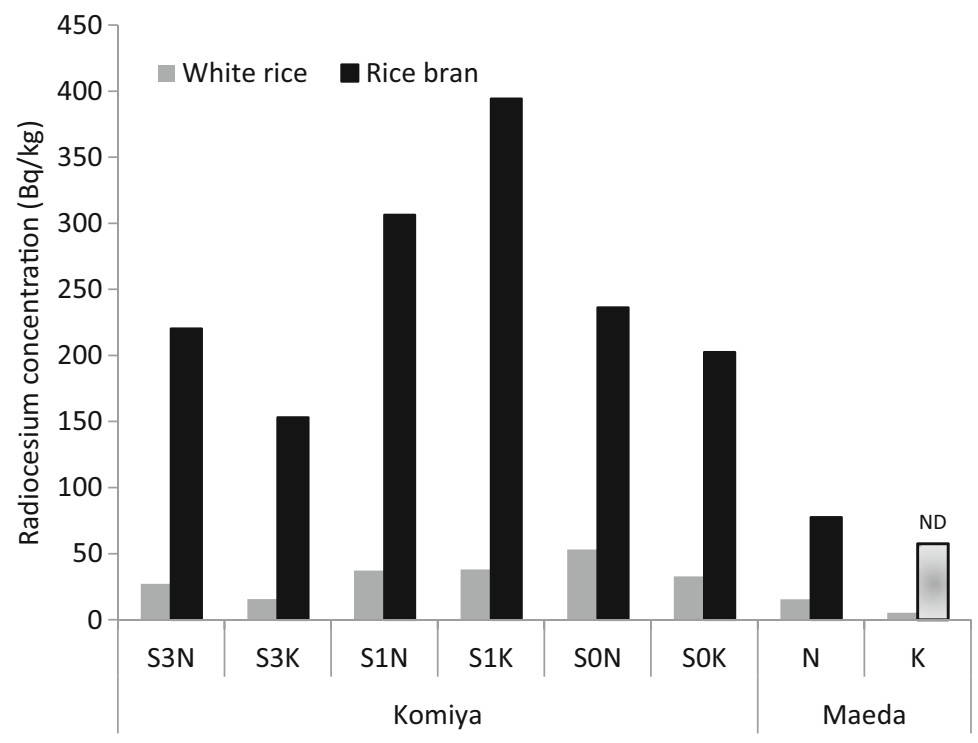

Fig. 6.21 Radiocesium concentration in white rice (left column) and rice bran (right column) harvested in each test field of Komiya and Maeda in 2013 (Ii et al. 2015). Refer to Fig. 6.18 legend for details of the test fields. ND shows that both ${ }^{134} \mathrm{Cs}$ and ${ }^{137} \mathrm{Cs}$ are below the detection limit. The height of the ND column shows the sum of the detection limits of ${ }^{134} \mathrm{Cs}$ and ${ }^{137} \mathrm{Cs}$ 
Komiya had 15-53 Bq/kg, whereas white rice from Maeda had $15 \mathrm{~Bq} / \mathrm{kg}$ in the field without $\mathrm{KCl}$ addition $(\mathrm{N})$ and $5 \mathrm{~Bq} / \mathrm{kg}$ in the field with $\mathrm{KCl}$ addition $(\mathrm{K})$. White rice from CDN in Sasu was $10 \mathrm{~Bq} / \mathrm{kg}$, and white rice from the other test fields were below the detection limit. Rice bran from Maeda and Sasu both had a maximum of $77 \mathrm{~Bq} / \mathrm{kg}$, which is below the new standard for food; however, rice bran from Komiya exceeded this standard.

\subsection{Conclusive Remarks}

We performed field trials of rice cultivation in partially decontaminated paddy fields in the Iitate Village in Fukushima prefecture in 2012, 2013, and 2014. The results of 2012 and 2013 show that suitable decontamination and addition of $\mathrm{KCl}$ can reduce the radiocesium concentrations in brown rice to values much lower than the safety standard for food in Japan $(100 \mathrm{~Bq} / \mathrm{kg})$. This trend is consistent with results in 2014, which are not detailed here. The rice harvested in 2012 and 2013 was not for consumption because it was a trial, even though it satisfied the standard levels. However, the members of ROF enjoyed eating the rice harvested at Sasu in 2014, after confirmation that the radiocesium concentration was below $25 \mathrm{~Bq} / \mathrm{kg}$ based on both our measurement of rice samples and the results from the Fukushima prefecture screening test of all bags of brown rice harvested in 2014. The members of ROF will continue to cultivate rice in the Iitate Village with the villagers to rebuild lives and reconstruct agriculture-centered industries.

Acknowledgments "All rice fieldworks were performed with the cooperation of Mr. Muneo Kanno, Agricultural Committee in the Iitate Village, Mr. Ryuzo Ito and Mr. Kin-ichi Ookubo in the Iitate Village, Dr. Masaru Mizoguchi at the University of Tokyo, Dr. Junko Nishiwaki at the Ibaraki University, and members of the Resurrection of Fukushima" (representative: Mr. Yoichi Tao). Sincere appreciation to the members of ROF and "Circle Madei" at Tokyo University particularly to Ms. Tomiko Saito and Mr. Yoshio Uno, for sample preparation for radioisotope measurements, and to Dr. Natsuko I. Kobayashi, Dr. Atsushi Hirose, Dr. Naoto Nihei, and Mr. Tatsuya Nobori at the Graduate School of Agricultural and Life Sciences, The University of Tokyo, for radioisotope measurement and valuable comments. We sincerely thank Mr. Ryuzo Ito who cooperated with us for the use of his field for experimental cultivation and for the fieldwork, and who passed away on September 23, 2013. We sincerely acknowledge his kind cooperation during his life and pray for his repose.

Field trials of rice cultivation in 2012 were performed under co-research agreement with NARO. The research was entitled "Rice cultivation in test fields decontaminated by rotary weeding tools and confirmation of volume reduction and stabilization technology of the harvest."

Open Access This chapter is distributed under the terms of the Creative Commons Attribution Noncommercial License, which permits any noncommercial use, distribution, and reproduction in any medium, provided the original author(s) and source are credited. 


\section{References}

Ii I, Tanoi KT, Uno Y, Nobori T, Hirose A, Kobayashi N, Nihei N, Ogawa T, Tao Y, Kanno M, Nishiwaki J, Mizoguchi M (2015) Radioactive cesium concentration of lowland rice grown in the decontaminated fields in Iitate-Village in Fukushima. Radioisotopes 64:299-310 (in Japanese with English summary)

Ministry of Agriculture, Forestry and Fisheries (2012) Results of test cultivation of agricultural products in the farm decontaminated (in Japanese) http://www.maff.go.jp/j/nousin/seko/josen/ pdf/sakutuke.pdf. Accessed Nov 2012

Ministry of Agriculture, Forestry and Fisheries (MAFF), Fukushima Prefecture (2013) Analysis of the factors to cause rice of high radiocesium and counteractions (in Japanese) http://www.pref. fukushima.lg.jp/download/1/youinkaiseki-kome130124.pdf. Accessed Jan 2013

Ministry of Agriculture, Forestry and Fisheries (MAFF), Fukushima Prefecture, NARO, National Institute for Agro-Environmental Sciences (NIAES) (2014) Analysis of the factors to cause rice of high radiocesium and counteractions. Rev.2 (in Japanese) http://www.maff.go.jp/j/ kanbo/joho/saigai/pdf/youin_kome2.pdf. Accessed Mar 2014

Mizoguchi M (2013) Remediation of paddy soil contaminated by radiocesium in Iitate Village in Fukushima prefecture. In: Nakanishi TM, Tanoi K (eds) Agricultural implications of the Fukushima nuclear accident. Springer, Japan, pp 131-142

National Agriculture and Food Research Organization (NARO) (2012) K fertilization to reduce radiocesium concentration (in Japanese) http://www.naro.affrc.go.jp/publicity_report/press/ laboratory/narc/027913.html Accessed Feb 2012

Nemoto K, Abe J (2013) Radiocesium adsorption by rice in paddy field ecosystems. In: Nakanishi TM, Tanoi K (eds) Agricultural implications of the Fukushima nuclear accident. Springer, Tokyo, pp 19-27

Nobori T, Tanoi K, Nakanishi T (2013) Method of radiocesium determination in soil and crops using a $\mathrm{NaI}(\mathrm{Tl})$ scintillation counter attached with a autosampler. Jpn J Soil Sci Plant Nutr (in Japanese) 84:182-186

Nobori T, Kobayashi NI, Tanoi K, Nakanishi TM (2014) Effects of potassium in reducing the radiocesium translocation to grain in rice. Soil Sci Plant Nutr 60:772-781

Ohmori Y, Kajikawa M, Nishida S, Tanaka N, Kobayashi NI, Tanoi K, Furukawa J, Fujiwara T (2014) The effect of fertilization on cesium concentration of rice grown in a paddy field in Fukushima prefecture in 2011 and 2012. J Plant Res 127:67-71

Resurrection of Fukushima (2012) Activity record in April, 2012. http://www.fukushima-saisei.jp/ archives/report201204.html. Accessed Apr 2012

Tsukada H, Hasegawa H, Hisamatsu S, Yamasaki S (2002) Rice uptake and distributions of radioactive ${ }^{137} \mathrm{Cs}$, stable ${ }^{133} \mathrm{Cs}$ and $\mathrm{K}$ from soil. Environ Pollut 117:403-409

Tsukada H, Takeda H, Takahashi T, Hasegawa H, Hisamatsu S, Inaba J (2005) Uptake and distribution of $90 \mathrm{Sr}$ and stable $\mathrm{Sr}$ in rice plants. J Environ Radioact 81:221-231

Uchida S, Tagami K (2007) Soil-to-plant transfer factors of fallout ${ }^{137} \mathrm{Cs}$ and native ${ }^{133} \mathrm{Cs}$ in various crops collected in Japan. J Radioanal Nucl Chem 273:205-210 